\title{
The Pastor and the Workingmen of His Parish
}

\author{
By Rev. Edwin V. O'Hara, LL.D. \\ Former Chairman, Oregon Industrial Welfare Commission
}

$\mathrm{T}$ IHE relationship of the pastor to his people is such as to warrant particular interest on his part in the welfare of the workingmen of his parish. Few Catholic parishes will be found in industrial centers in which the laboring men do not constitute a very large percentage of the congregation. The obvious duty of entering into the problems of his laboring men, incumbent on the Catholic priest, has, moreover, been more than once enforced by specific instructions from the Sovereign Pontiff. In his famous encyclical on the "Condition of the Working Classes," Pope Leo XIII, after setting forth the social program of the Church, concludes by explicitly placing on the clergy, in union with their bishops, the task of persistent and energetic action in behalf of the laboring class. He writes: "Every minister of holy religion must throw into the conflict (in behalf of social justice and charity) all the energy of his mind and all the strength of his endurance." Similar injunctions have been addressed to the clergy by Pius $\mathrm{X}$ and Benedict XV.

In fulfilling these injunctions the pastor will find that his activities in behalf of his workingmen will fall into three general channels, the currents of which flow largely in the same direction and frequently converge. These channels are education, organization, and legislation.

\section{Education}

It will be the duty of the pastor in industrial centers to explain to his people clearly and frequently the Christian laws of justice and of charity as they affect employer and employee. He will point out with Leo XIII that a great error in the discussion of industrial problems is to possess one's self of the idea that class is naturally hostile to class; that rich and poor are intended by nature to live at war with one another. On the contrary, each requires the other; capital cannot thrive without labor, nor labor without capital. He will go on to teach that religion requires the laboring man to carry out honestly and well all equitable agreements fairly made; never to injure capital, nor to outrage the person of an employer; never to employ violence in representing his own cause, nor to engage in riot and disorder. Religion, he will continue, teaches the employer that his working people are not his slaves; that he must respect in every man his dignity as a Christian; that labor is nothing to be ashamed of, but that it is shameful and inhuman to treat men like chattels in order to make money, or to look upon them as merely so much muscle or physical power; that the employer must see that his workmen have time for their duties of piety and the obligations of their family life; that they must not be taxed beyond their strength or employed in work unsuited to their sex or age; that the workmen are entitled to a living wage, and that to exercise pressure for the sake of gain upon the indigent and destitute, and to make one's profit out of the need of another, is condemned by all laws, human and divine. These principles will be the staple of instruction by which the pastor will seek to educate his people to a Christian conscience in regard to the relations of employers and workmen; for,"were these precepts 
carefully obeyed and followed out," asks Leo XIII, "would not strife die out and cease?"

But the pastor cannot be satisfied with mere instruction and exhortation. This was thoroughly understood by Bishop Ketteler, when he put into the mouths of the infidel workmen of his day the following words: "Of what use are your fine teachings to me? What is the good of your referring me by way of consolation to the next world, if in this world you let me and my wife perish with hunger; you are not seeking my welfare, you are looking for something else."

\section{Organization}

It will devolve on the pastor to undertake to assist his workingmen by organization and legislation. Most of the progress made by the working classes in recent time has been due to organization, and it will be the duty of the clergy to encourage every form of workmen's association which legitimately promotes the workmen's interests. Much has been written concerning freedom of contract and the importance of allowing each man to bargain for himself. After a long and painful struggle the workingman has realized that there is no equality of bargaining power when the individual workman is pitted against the large employer. For freedom of contract it is necessary that the workingmen combine and bargain collectively with their employers, so that there may be some semblance of equality between the two contracting parties. The so-called American plan whereby the employer refuses to deal with his employees collectively is, under a specious pretense of liberality, merely a hollow sham. The power of the employer to withhold bread is a vastly greater advantage than the power of the individual employee to refuse to labor. To speak of freedom of contract between the individual employee, whose family may be on the verge of starvation, and the modern accumulation of capital that seeks to employ labor, is simply grotesque humor. The importance of workmen's associations is set forth by Leo XIII and the encouragement of labor unions will properly claim the interest of the parish priest.

It will, however, not be sufficient to encourage the organization of labor associations, and to promote an increase of their membership, but it will be necessary for the pastor to impress upon the members of the unions who belong to his own congregation the importance of electing good men to leadership, and of recognizing that the union is not merely an economic institution but has moral aspects as well. Perhaps the gravest injury done to the cause of labor in our time has been through unprincipled leaders and a disregard of the moral principles which must provide the basis of permanent association.

In the field of coöperation laboring men have successfully maintained stores which have proven a boon to their members. One form of coöperation deserves especial attention: namely, the establishment of a coöperative credit association in a parish which will free the laboring man from the clutches of the loan shark, and will enable him to secure necessary advances of money on reasonable terms and without placing him in the power of the lender. Finally, the establishment of parish study groups among laboring men will be found of great service as a means of inculcating Christian principles in regard to these economic issues.

\section{Legislation}

The utility of organization cannot be questioned. Nevertheless, there are limits to its successful activity. There 
are great groups of working people whom it is difficult to organize, and up to the present only a comparatively small percentage of workers are actually organized. It is the duty of the state to prevent any class of the population from becoming submerged, and consequently the pastor will, in his solicitude for his people, urge the necessary legislation to protect them. The problem of the inadequacy of women's wages is present in most American cities, and the program for minimum wage legislation should secure the hearty coöperation of the clergy.

Experience has shown that such legislation is not attended by the disadvantages which are commonly urged against it. A word of caution, however, should be uttered in regard to the arguments which should be used in urging minimum wage legislation. There is a temptation to make a sensational appeal setting forth the moral dangers which surround inadequately paid young women in industry. The difficulty with this line of argument is that it is largely an insult to the workers whose status is to be improved, and it leads to a neglect of the substantial fact that these underpaid workers are living on insufficient food, are badly housed and poorly clothed.

A similar interest will be manifested by the pastor in the limitation of hours of labor, both of women and of men, especially in the prohibiting, as far as possible, of Sunday work and of late night work. I recall that when the Industrial Welfare Commission of Oregon first entered a ruling prohibiting work for women after six p.m. in the department stores, many young women had for the first time in months a rea- sonable opportunity to go to church Sunday morning.

Workmen's compensation legislation has now come in most of our states, and with it the abolition of the common law pleas of contributory negligence and assumption of risk, which enabled the liability insurance companies to prevent the injured workman from receiving compensation; but the principle of compensation needs to be maintained and extended, the importance of safety devices on machinery insisted upon, and many occupational diseases should be brought under the operation of compensation.

The pastor will be concerned, also, with the living conditions of his working people, and will feel it his duty to promote an adequate housing code, which will require the homes of his people to be furnished with sufficient sunlight and fresh air, and open spaces for children's recreation. It will be necessary to resist the wild and unscrupulous advertising of city commercial clubs, which lead multitudes of unskilled laborers to congregate in congested centers, flooding the labor market and overcrowding the tenements. I have attended dying men in workingmen's hotels in rooms where no light but that cast by the flickering flame of the gas jet ever penetrated. Such conditions will be found wherever there is a lack of adequate housing legislation, or a neglect of its enforcement.

The pastor, too, will be interested in the promotion of legislation regulating employment bureaus, preventing the exploitation of men who pay for their jobs. The old story of the three groups of men on a job, the one going, the one coming, and the one working, is a grim commentary on unregulated employment offices. 